\title{
DNA CONTENTS AND CELL NUMBER IN RELATION TO SEED SIZE IN THE GENUS VICIA
}

\author{
D. ROY DAVIES \\ John Innes Institute, Colney Lane, Norwich NR4 7UH
}

Received 17.i.77

\begin{abstract}
SUMMARY
The extent of variation in cell mass, and in the size of the cell population of cotyledons has been examined to determine their relative roles in the evolution of variation in seed weight within the genus Vicia. In the 12 species examined there were highly significant correlations between seed weight and cotyledon cell number, and between seed weight and mean cell mass. The extremes differed by a factor of 625 fold in dry seed weight; of this variation, most (140 fold) was attributable to variation in the size of the cell population and only a 4.47-fold change was due to differences in cell mass. The cotyledon cells of all the species, irrespective of their seed weight showed very high levels of replication of their DNA. The implications of these data in terms of the evolution of seed mass in Vicia is considered. There was a constant relationship between cell mass and DNA amount per cell for all species, irrespective of the basic genome size, extent of DNA replication or of the information content of the genome. The basis of this relationship, and its evolutionary implication, is considered.
\end{abstract}

\section{INTRODUCTION}

Substantial variation in the size of seeds exists both between and within different species of plants (Harper et al., 1970; Salisbury, 1974). While the evolutionary significance and ecological implication of these variations have been the subject of considerable discussion, the cellular and molecular basis of the variation in size is for the most part not understood. Yet the seed is the economically important component of many of our crop plants and a greater knowledge of its biology is of significance in programmes of crop plant improvement. Physiological studies have not resolved the relative roles of the sources of photosynthate, of the capacity or strengths of the sinks within the seed, and of the translocation system between them in determining the size of the seed (Evans, 1975). Sink strength and size has not been defined in terms of enzymatic activities, hormone levels, nucleic acid and protein metabolism, nor in terms of cell numbers and cell mass (Dure, 1975). Within the species Pisum sativum it has been shown that the variation in seed size between different genotypes is associated with both a change in the number of cells within the cotyledons and in the mean weight of those cells. The mean cell weight is in turn related to mean DNA and ribosomal RNA amounts (Davies, 1975; Davies and Brewster, 1975; Davies, 1976), but the factors regulating the latter parameters have only begun to be examined in studies of the role of ribosomal RNA cistron numbers (Cullis and Davis, 1975) and of RNA polymerase levels (Cullins, 1976). Bennett (1972) and Jones and Brown (1976) demonstrated a relationship between seed mass and the diploid (2C) arnount of DNA in the genome of different species within the genera Vicia, Allium and Crepis, although in all these instances there was a considerable amount of variation not accountable in terms of change in $2 \mathrm{C}$ DNA contents. The present study has sought to examine the basis of the 
approximately 600 -fold difference in seed size that exists between different species within the genus Vicia.

\section{Materials AND MEthods}

The following species were used Vicia angustifolia (BA46); V. bithynica (BA8); V. disperma (BA7); V. ervilia (BA18); V. grandiflora (BA25); V. lutea (BA34); $V$. narbonensis (BA37); $V$. pubescens (BA43); $V$. sativa (BA44); $V$. villosa (BA66); $V$. faba major cv. Green Windsor; $V$. faba minor cv. Maris Bead (BA71). I am indebted to Dr E. Griffiths, Institute of Rural Science, University of Wales, Aberystwyth, for kindly providing the seed of these species.

Cell counts were made following digestion of the cotyledons with chromic acid for 24 or 48 hours at room temperature (Rijven and Wardlaw, 1966). Four replicate samples, each of 10 separate counts were used to determine each value. The values quoted are the final cell numbers after cessation of cell division. DNA was extracted by homogenising a known weight of tissue in buffer $(50 \mathrm{~mm}$ Tris $p H 8.0,10 \mathrm{~mm}$ mercaptoethanol, $2 \mathrm{~mm}$ magnesium chloride; 5 per cent glycerol; $1 \mathrm{mg} / \mathrm{ml}$ polyvinylpyrrolidone), spinning at $100,000 \mathrm{~g}$ for 30 minutes, washing the pellet twice in buffer, precipitating with 2 vols of ethanol, spinning again at $100,000 \mathrm{~g}$ then digesting the pellet in 5 per cent perchloric acid at $70^{\circ} \mathrm{C}$ for 30 minutes. The DNA was estimated by a diphenylamine method (Schneider, 1957). For the mature

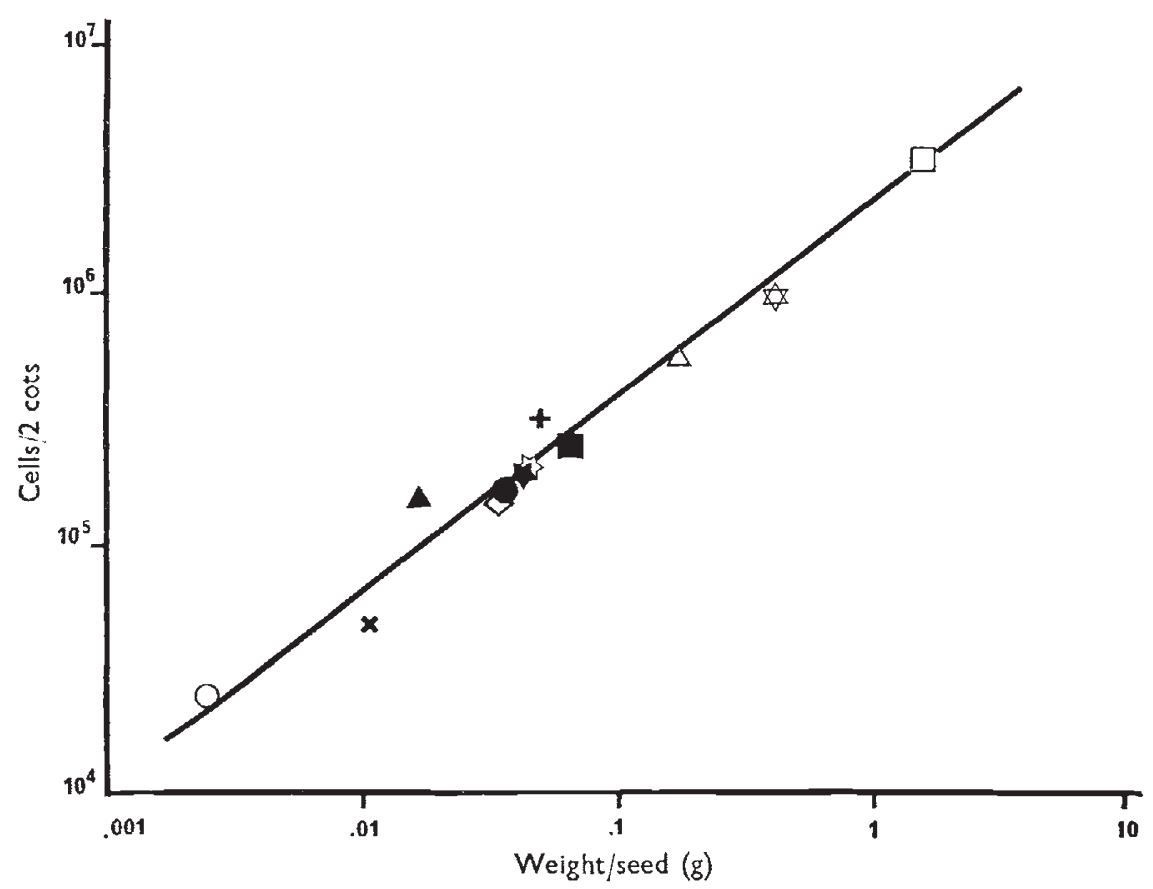

FIC. 1.--Relation between numbers of cells in the two cotyledons and the dry wcight of a seed in different species of Vicia. $O=V$. pubescens; $x=V$. angustifolia; $\boldsymbol{\Delta}=V$. disperma; $\diamond=V$. sativa; $\mathbf{O}=V$. ervilia; $\boldsymbol{\forall}=V$. grandifora; $\boldsymbol{i}=V$. villosa $+=V$. lutea; $\because=V$. bithynica; $\triangle=V$. narbonensis; $\$=V$. faba minor $\square=V$. faba major. 


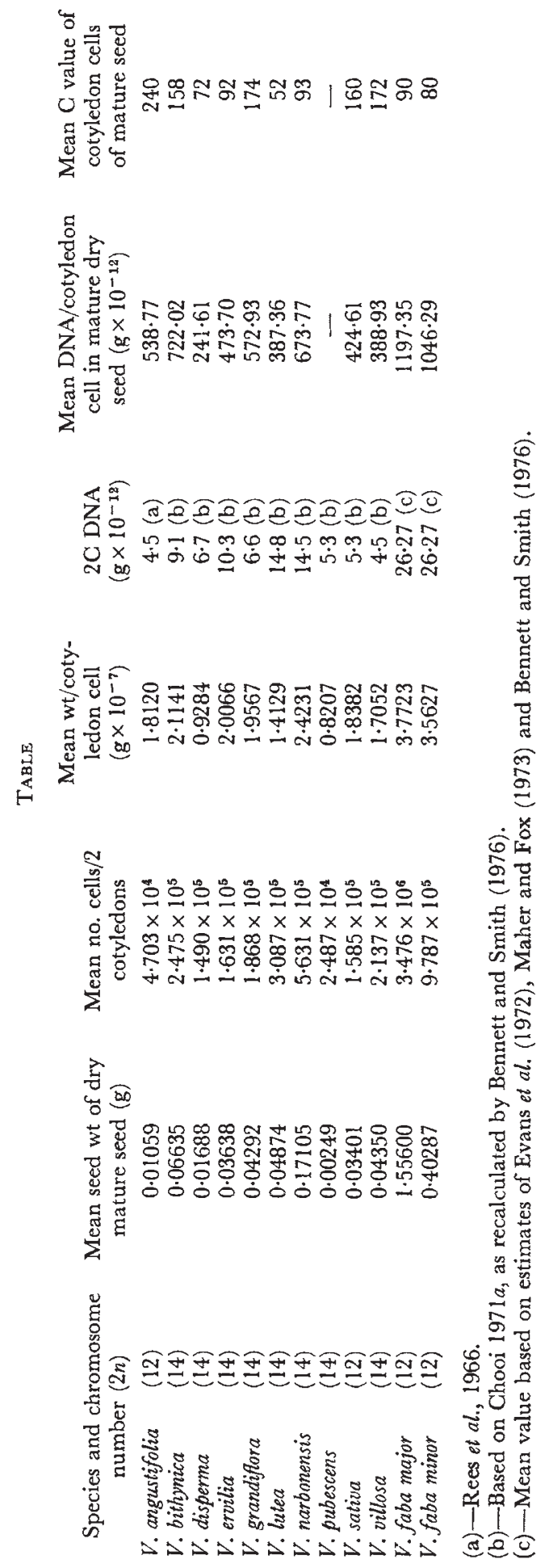


seed, three replicate estimates were made per species. In the case of the developing cotyledons, each sample was estimated separately, and the value related to its fresh weight. Replicate samples were not readily attainable for any given developmental age. Dry weights of mature sceds were determined aftcr equilibration over calcium chloride.

\section{Results}

Within the Vicia species examined a highly significant correlation $(\mathrm{P}<0.001)$ exists between the final number of cells in the cotyledons of a seed, and the dry weight of that mature seed. (The weights of the cotyledons represent approximately 85 per cent of the total dry weight of seed.) The correlation holds over the 625 -fold variation in the dry weight of seed, from the mean value of $0.00249 \mathrm{~g}$ in Vicia pubescens to $1.556 \mathrm{~g}$ in $V$. faba major. The mean numbers of cells in the pair of cotyledons of these two species are $2.487 \times 10^{4}$ and $3.476 \times 10^{6}$ respectively. The slope of the $\log / \log$ relationship (fig. 1) is $0 \cdot 7628 \pm 0 \cdot 0402$, indicating that the rate of increase in cell number diminishcs with increasing seed weight.

The average weight of the cotyledon cells differs in the species examincd (see table) with the mean being related to mature dry sced weight $(\hat{b}=$ $0.4900 \pm 0.0686$ for the $\log$ /lincar relationship, $\mathrm{P}<0.001)$. The maximum extent of the diffcrence in cell weight is 4.47 -fold with again a more rapid initial rate of increase. This is in contrast to the 140 -fold variation in cell

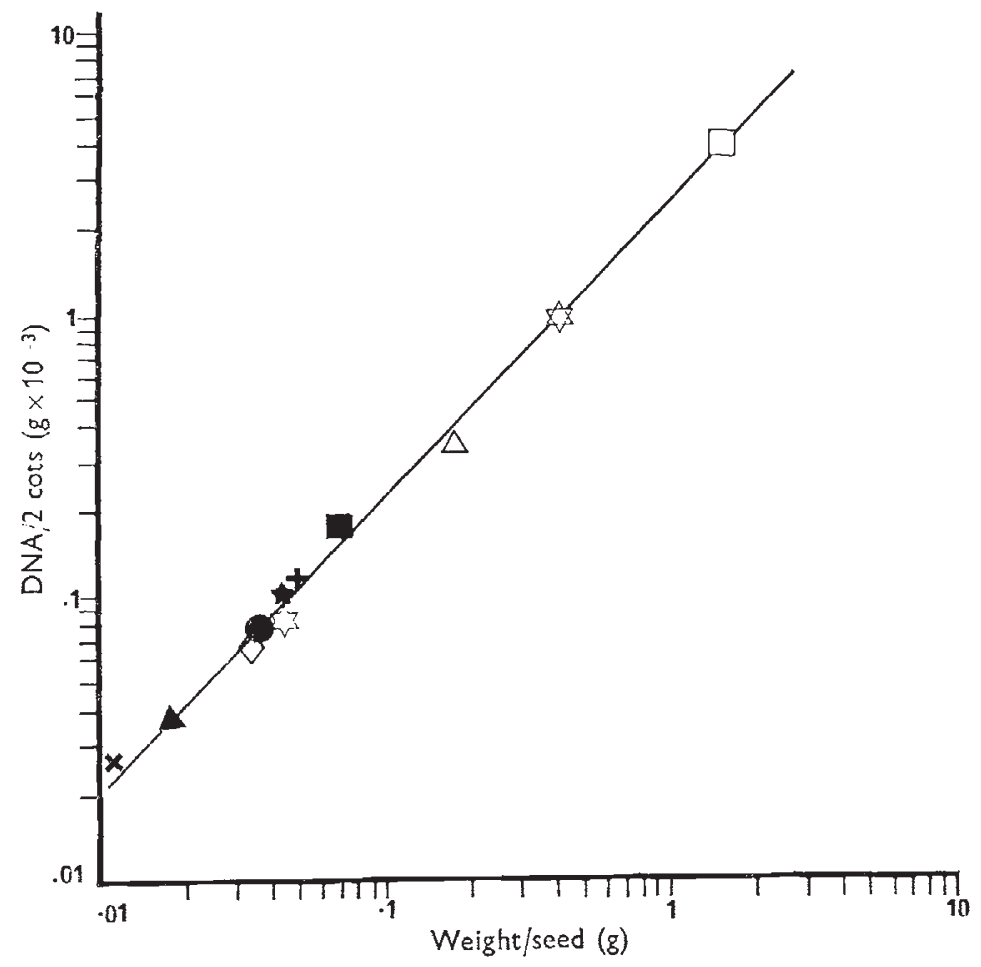

FIG. 2.-Relation between DNA per two cotyledons and weight, in mature dry seed of different species of Vicia (symbols as in fig. 1). 
number. Thus while the evolution of larger seeded forms within the genus Vicia has been achieved as a result of two mechanisms, the increase in cell number has been by far the more important.

It has been observed in many systems that cell weight is correlated to nuclear DNA content (Ycas et al., 1965; Martin, 1966). DNA amounts present in the cotyledons were determined both for mature dry seed, and for a range of developmental stages during the maturation of the seed. A highly significant linear relationship existed between DNA content and seed weight in the mature dry seed $(\hat{b}=1.0413 \pm 0.0229$ for the $\log / \log$ relationship, $\mathrm{P}<0.001$ ) (fig. 2). For the range of developmental stages the relationship was not quite linear $(\hat{b}=0.8949 \pm 0.0213$ for the $\log / \log$ relationship, $\mathrm{P}<0.001$ ) (fig. 3). Thus in the dry seed a unit increase in weight is associated with a constant increase in the amount of DNA, irrespective of the number of cells present, or of the differing basic genome sizes in the different species. This is expected if cell weight is directly related to DNA content, and such a relationship is observed $(\hat{b}=0.2842 \pm 0.0221, \mathrm{P}<0.001)$ (fig. 4). Using the published values (Chooi, 197la; Bennett and Smith, 1976) for the $2 \mathrm{C}$ amounts of DNA, the average extent of the replication of DNA within the cotyledon cells of each species was calculated (table). These data confirmed the high DNA contents and high $\mathrm{C}$ values per cell that have been observed in the cotyledon cells of legumes. They furthermore indicated that the cells of those species which had the smallest $2 \mathrm{C}$ values showed the

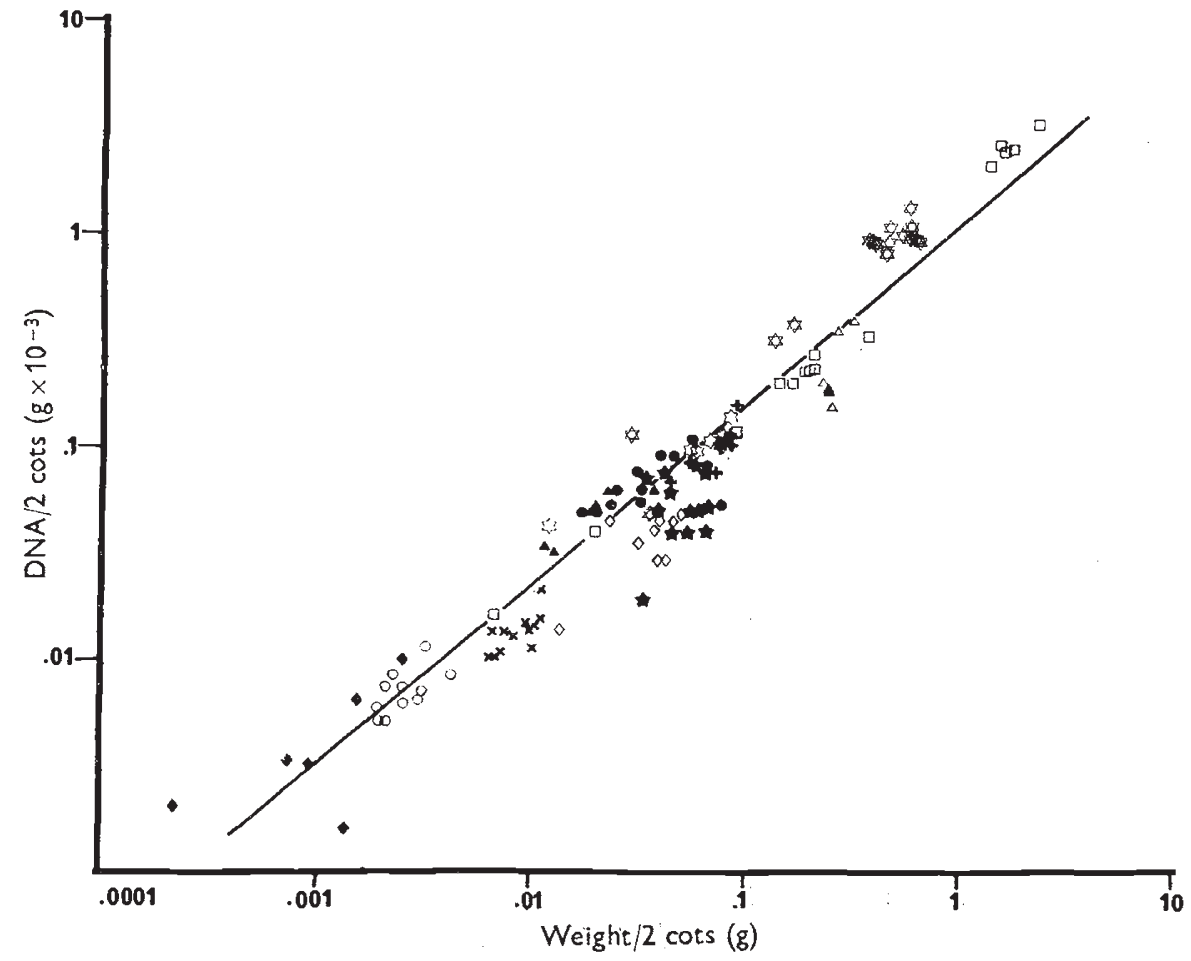

FIG. 3.- Relation between DNA and wet weight in cotyledons of a range of developmental stages in different species of Vicia (symbols as in fig. 1). 
greatest extent of DNA replication in their cotyledons. The mean $\mathrm{G}$ value obtained for $V$. faba cotyledon cells is higher than that quoted by Millerd and Whitfield (1973); they reported a calculated mean value of $16 \mathrm{C}$ although this should be $25 \mathrm{C}$ if the average of three similar $2 \mathrm{G}$ values obtained by Evans et al. (1972), Maher and Fox (1973) and Bennett and Smith (1976) of $26.27 \times 10^{-12} \mathrm{~g}$ is accepted as the correct one.

\section{Discussion}

The variation in seed size that is observed between the different species of Vicia cannot be directly related to any evolutionary phylogenetic sequence since this has not been established for the species concerned. Nevertheless, irrespective of whether or not the evolutionary trend is towards an increase in seed weight, as seems likely by analogy with other crop plants and their ancestral relatives, the means by which the change in weight has occurred can now be established. The primary mechanism has been an increase in size of the cell population within the cotyledons, with an increase in cell weight a secondary and less important factor. Bennett (1972) observed a relationship $(\mathrm{P}<0.01)$ between seed mass and $2 \mathrm{C}$ DNA amount in seven species of Vicia, although in doing so he omitted one form, V. faba major, which clearly did not agree with the relationship. Bennett (1972) and Jones and Brown (1976) also observed a relationship between 2C nuclear DNA amounts

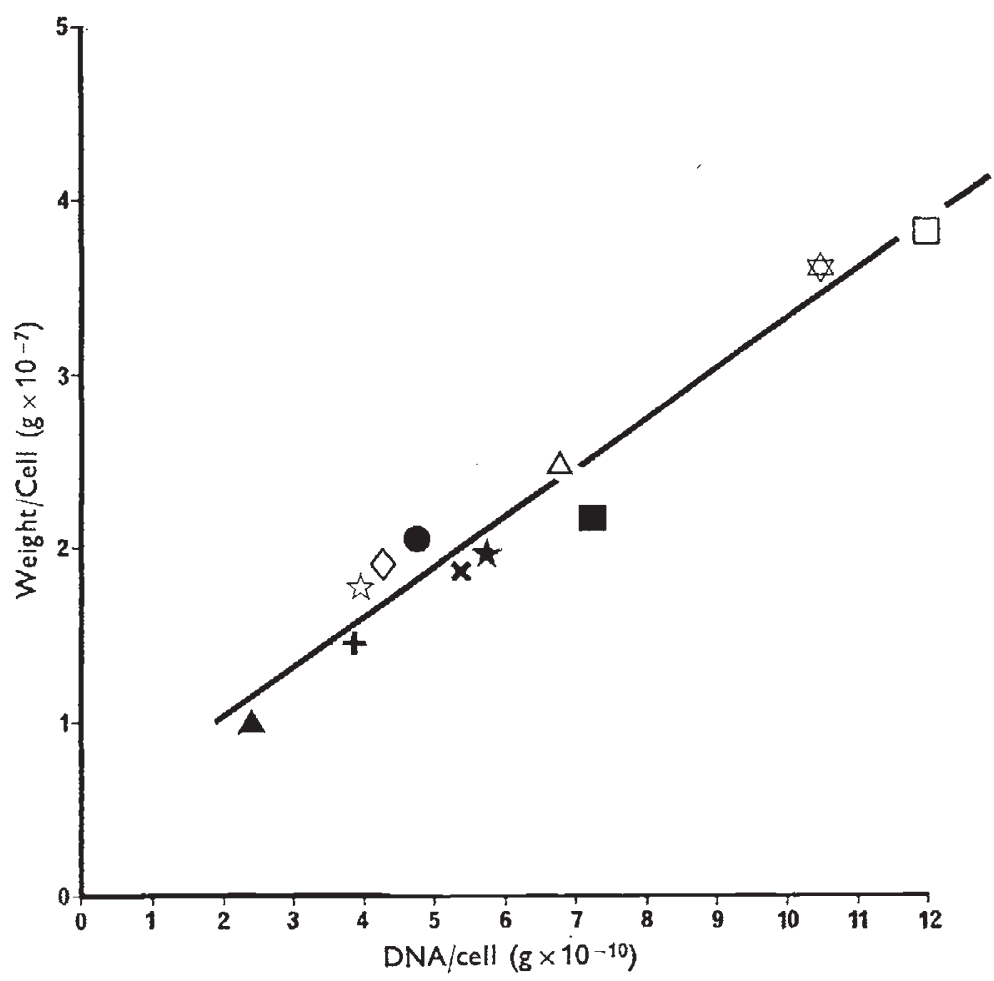

Frg. 4.-Relation between DNA amount and weight, per cotyledon cell in dry mature seed of different species of Vicia (symbols as in fig. 1). 
and seed weight in 12 species of Allium and in 16 species of Crepis respectively. While a general relationship of the kind described certainly exists and has been confirmed in the present investigation, variation in cell number is of far greater significance in accounting for variation in seed weight within the group of Vicia species, than is the $2 \mathrm{C}$ amount of DNA. In considering evolutionary changes in seed weight, be they towards small or large seed, the necessary flexibility almost certainly will have been achieved more readily by an adjustment either of the size of the cell population or by the extent of the replication of the DNA with its concomitant change in cell size, rather than by changing the basic genome size. It is important to note that even in species with the smallest seed, the DNA in the cotyledon cells is replicated to very high values - up to $240 \mathrm{C}$. It had been considered that their small size might have been associated with a lower extent of, or possibly no, replication of DNA beyond the diploid level; clearly this is not the case and polyteny or polyploidy in these cells has been an essential feature of their development.

Although variation in cell weight and cell number are mentioned as separate strategies by which change in seed weight is attained, the two appear to be correlated. One possible explanation for this follows. As increases occurred in the nuclear DNA amounts, due to chromosomal duplication and/or DNA amplification (Rees, 1972), this would be associated with an increase in average cell mass. The bigger cells would lead to an increase in leaf area which in turn would provide an increased supply of photosynthate. This could allow greater meristematic activity within the cotyledons, and hence the development of a larger cell population, and also allow a greater subsequent growth of the cells (fig. 5). The increases in cell number per leaf that accompany the increases within the seed (D. R. Davies, unpub. obs.) can be explained in similar terms. Although species of Vicia with the largest seed have the largest leaf areas, it is difficult to define precise values for the latter, as leaflet area and number vary markedly with developmental stage. In the evolution of species of wheat it has also been observed that increased grain size is accompanied by parallel increases in flag leaf area, although their cellular bases are undefined (Evans and Dunstone, 1970). In this group, as in the Viciae (D. M. Harvey, pers. comm.), photosynthetic efficiency per unit area of leaf has not increased in the larger seeded species.

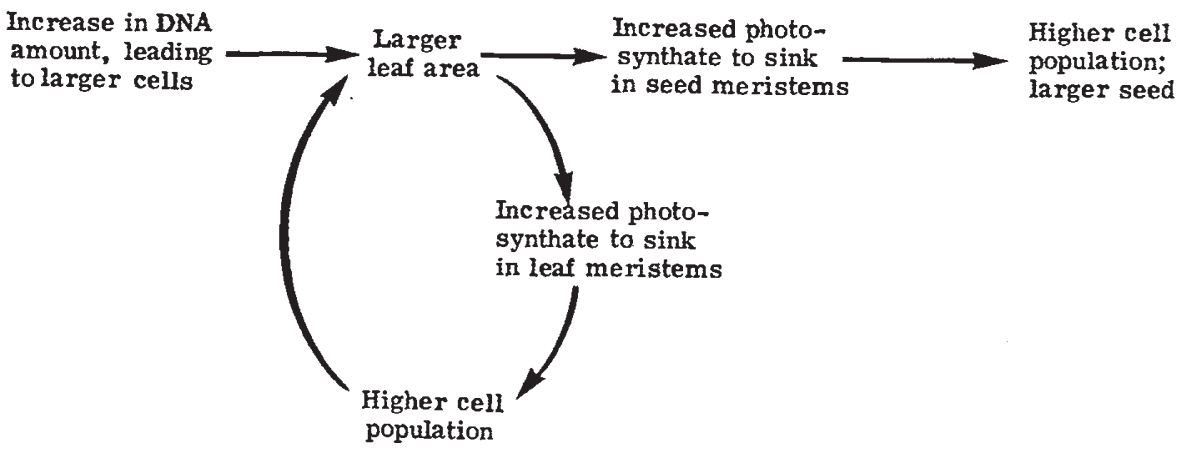

FIG. 5.- Schematic representation of the possible consequences of an increase in cell size on leaf area and on seed mass. 
This interpretation of the consequence of increase in DNA per nuclcus may provide another clue to the paradox of the enormous variation in DNA amount per cell that exists within the plant kingdom-a variation far in excess of that found for example in mammals and birds (Rees and Jones, 1972). The function and selective advantage or disadvantage of the additional DNA has been an enigma, although Rees (1972) has pointed out the important effects of DNA amount on cell mass and rate of cell division, and Bennett (1972) the effect on life cycle. Rees and Jones (1972) considered other effects, and that mentioned here-the consequential effect of DNA increase on leaf area would also have significant implications both in terms of increasing the photosynthetic area and also in swamping competitors, and would be a character subject to selection during evolution. The increase in leaf area observed in the evolution of the cultivated wheats (Evans and Dunstone, 1970) and the improved performance of forms with larger leaves in a variety of crops (Watson, 1952; Wallace et al., 1972) supports this last contention. In no sense does this imply that changes in leaf area cannot be attained also by changes in specific structural and regulatory gencs.

The linear relation between mean $\mathrm{DN} \Lambda$ content and mean dry weight of cells is confirmed in the present data. The nuclei of the cotyledon cells of legume seeds can develop high DNA values--up to 64C being reported in Pisum arvense (Smith, 1973) and Pisum sativum (Sharpe and van Parijs, 1973; Millerd and Spencer, 1974; Davies and Brewster, 1975) and up to a mean value of $100 \mathrm{C}$ in Pisum sativum by Cullis (1976). In Vicia faba Millerd and Whitfield (1973) reported a mean value of $16 \mathrm{C}$, although as stated earlier this might well be more appropriately calculated to be $25 \mathrm{C}$. The relationship between DNA content and dry weight per cell exists over the whole range of Vicia species which were examined, although these have different basic genome sizes, different information content within their DNA and different extents of replication of their DNA. The extent of the diversity of the DNA of these species has been studied to only a limited extent but marked differences were observed in the proportion of highly repeated sequences among six species studied (Chooi, 1971b). Although the amount of DNA and the mass of the cell are related, the nature of the control is not understood. Ycas et al. (1965) suggested a model of cell size regulation by the DNA in which an unstable gene product is maintained at a constant amount per cell; its concentration would then be a function of cell size, and as the concentration dropped with increasing cell growth so protein synthesis would cease. In polyploid cells a greater number of copies of the gene would increase the amount of gene product and thus the cell size. Such a proportionality is observed in the cotyledon cells in the present experiments, as the cells increase their DNA contents with developmental stage. The different species of Vicia, however, have differing amounts of DNA, wholly unrelatcd to varying levels of ploidy, and have differing proportions of repeated and non-repeated DNA sequences (Chooi, 1971b). Yet, in spite of this, all the different species and all the differing levels of DNA in the cells of any one species show the same constant relationship between DNA amount and cell mass. According to the Ycas et al., model, it would be necessary for the species to still have numbers of copies of the relevant gene in direct proportion to their total DNA content. There could be a precedent for such a relationship in the numbers of rRNA cistrons present in four species of Vicia, where Maher and Fox (1973) showed that the numbers of rRNA 
genes are in proportion to the DNA content of the species. Not only would this numerical relationship have to be valid for all the species examined but also it would have to be demonstrated that there was an equal utilisation of all the genes in all instances. In the case of rRNA genes Ingle et al. (1976) have failed to demonstrate an equal utilisation of rRNA genes in a number of species which had vastly differing numbers, i.e. they failed to demonstrate a link between cistron number and amount of gene product. Furthermore, in another group of related species within the genus Nicotiana, there was no relation between DNA amount per nucleus and rRNA gene number (Cullis, 1975).

Other models of cell size regulation have been proposed (Fantes et al., 1975), some of which invoke a regulation dependent on cytoplasmically produced materials being monitored by the genome. Clearly the cytoplasm is here assumed to have a primary regulatory function, and this is implicit in the result sof experiments with certain microbial systems (Weiss et al., 1975). The data on which these models are based have been obtained mainly from studies of a given organism in which growth and division cycles have been perturbed in various ways. In the present studies the relation observed is based on a range of species of differing genetic constitutions. In all these species, therefore, there is a common mechanism of sensing the ratio DNA : cell mass and this is difficult to explain in terms of particular genes and their products because either they would have to be present in numbers which are proportional to the total DNA mass, or the regulation of their activity would have to be proportional to this mass. The difficulty, therefore, in this consideration is to identify a DNA component which would be related to the mass but not necessarily to the information content of the genome. One possibility would be the initiation sites for DNA replication. Both the time for DNA replication and total cycle time are directly related to DNA amount (Van't Hof and Sparrow, 1963; Evans et al., 1972). In the few unrelated organisms examined, an increased amount of DNA and hence an increased time of DNA synthesis has not been associated with a clear-cut change in number of initiation sites (Callan, 1973; Van't Hof, 1975); the situation in closely related species has not been established. Within different tissues of a given species, change in the timing of DNA synthesis and of mitotic cycles can be associated with changes in number of initiation sites (Callan, 1972); clearly, therefore, their activity can be regulated. The way in which regulation of replication rate, DNA amounts, cell cycle time and cell mass are interrelated clearly remains to be established but a regulation mediated by cell mass on initiation sites is one possibility.

Acknowledgments. - I am indebted to Mrs V. Brewster and Mr N. Sanders for their technical assistance.

\section{REFERENCES}

BENNETT, M. D. 1972. Nuclear DNA content and minimum generation time in herbaceous plants. Proc. Roy. Soc. Lond., B, 181, 109-135.

BENNETT, M. D., AND SMITH, J. B. 1976. Nuclear DNA amounts in angiosperms. Phil. Trans. Roy. Soc. Lond., 274, 227-274.

Callan, H. G. 1972. Replication of DNA in the chromosomes of eukaryotes. Proc. Roy. Soc. Lond., B, 181, 19-41.

CALlaN, H. G. 1973. DNA replication in the chromosomes of eukaryotes. Cold Spring Harbour Symposium in Quantitative Biology, Vol. XXXVII, pp. 195-203.

$39 / 1-\mathrm{L}$ 


\section{ROY DAVIES}

crroor, w. y. 1971a. Variation in nuclear DNA content in the genus Vicia. Genetics, 68, $195-211$.

c:Hoor, w. Y. $1971 b$. Comparison of the DNA of six Vicia species by the method of DNADNA hybridization. Genetics, 68, 213-230.

cullis, a. A. 1975. Ribosomal RNA cistron number in Nicotiana species and derived haploids. Chromosoma (Berl.,), 50, 435-441.

GULLIS, c. ^. 1976. Chromatin-bound DNA-dependent RNA polymerase in developing pea cotyledons. Planta (Berl.), 131, 293-298.

Gulits, a. A., AND Davies, D. R. 1975. Ribosomal DNA amounts in Pisum sativum. Genetics, $81,485-492$.

vnvies, D. R. 1975. Studies of seed development in Pisum sativum. I. Seed size in reciprocal crosses. Planta (Berl.), 124, 297-302.

DAvies, D. R. 1976. DNA and RNA contents in relation to cell and seed weight in Pisum sativum. Plant Sci. Lett., 7, 17-25.

DAVIES, D. R., AND BREWSTER, v. 197.5. Studies of sccd development in Pisum sativum. II. Ribosomal RNA contents in reciprocal crosscs. Planta (Berl.), 124, 303-309.

Dure, L. s. 1975. Seed formation. Ann. Rev. Plant Physiol., 26, 259-278.

EVANS, G. M., REES, H., SNELL, C. L., AND SUN, s. 1972. The relationship between nuclear DNA amount and the duration of the mitotic cycle. Chromosomes Today (ed. C. D. Darlington and K. R. Lcwis), 3, 24-31.

Evans, x. T. 1975. The physiological basis of crop yield. In Crop Physiology, ed L. T. Evans, pp. 327-355. Cambridge University Press.

Evans, L. T., AND DUNSTONE, R. L. 1970. Some physiological aspects of cvolution in wheat. Aust. J. biol. Sci., 23, 725-741.

FANTFS, P. A., GRANT, W. D., PRITChARD, R. H., SUDbERy, 1. E., AND WIIEALS, A. E. 1975. The regulation of cell size and the control of mitosis. 7. Theor. Biol., 50, 213-244.

IIARPER, J. L., LOVELl, P. II., AND MOORE, K. (*. 1970. The shapcs and sizes of secds. Ann. Rev. Ecology and Systematics, 1, 327-356.

INGLF, I., TIMMIS, Y. N., AND GORE,,. R. 1976. Quantitativc regulation of gene activity. In Perspectives in Experimental Biology-vol. 2, Botany, ed. N. Sunderland, pp. 273-281.

JUNES, R. N., AND BROWN, L. M. 1976. Chromosome evolution and DNA variation in Crepis. Heredity, 36, $91-104$.

MAHER, F. P., AND FOX, D. P. 1973. Multiplicity of ribosomal RNA genes in Vicia species with different nuclear DNA contents. Nature New Biol., 245, 170-172.

MARTIN, p. G. 1966. Variation in the amounts of nucleic acids in the cells of diffcrent species of higher plants. Exp. Cell Res., 44, 84-94.

MLI,ERD, A., AND SPENCER, D. 1974. Changes in RNA-synthcsizing activity and template activity in nuclei from cotylcdons of developing pea sceds. Aust. J. Plant Physiol., 1, $331-341$.

MILLERD, A., AND WHITFIELD, P. R. 1973. Deoxyribonucleic acid and ribonuclic acid synthesis during the cell expansion phase of cotyledon dcvclopment in Vicia faba L. Plant Physiol., 51, 1005-1010.

REES, H. 1972. DNA in higher plants. In Evolution of Genetic Systems. Brookhaven Symposium in Biology, No. 23, ed. H. H. Smith, pp. 394-418.

RTES, H., CAMERON, F. M., HAZARIKA, M. H., AND JONES, G. H. 1966. Nuclear variation between diploid Angiosperms. Nature, Lond., 211, 828-830.

REES, H., AND JONES, R. N. 1972. The origin of the wide species variation in nuclear DNA contents. Int. Rev. Cytol., 32, 53-92.

RIJVEN, A. I. G. C., AND WARDIAW, t. F. 1966. A method for the determination of cell number in plant issues. Exp. Cell Res., 41, 324-328.

Salisbury, E. 1974. Seed sizc and mass in relation to environment. Proc. Roy. Soc., B, 186, 83-88.

sCIIARPT, A., AND VAN PARIJs, R. 1973. The formation of polyploid colls in ripening cotyleclons of Pisum sationu $\mathrm{L}$. in relation to ribosome and protcin synthesis. 7 . exp. Bot., 24, $216-222$.

scintmer, w. a. 1957. Determination of nucleic acids in tissue by Pentose analysis. Methods in Enzymol., III, 680-691.

sMirt, D. L. 1973. Nucleic acid, protein and starch synthesis in developing cotyledons of Pisum arvense L. Ann. Bot. (Lond.), 37, 795-804.

VAN'T nor, J. 1975. DNA fiber replication in chromosomes of a higher plant (Pisum sativum). Exp. Cell Res., 93, 95-104.

VAN'T HOF, J., AND SPARROW, A. H. 1963. A rclationship bctween DNA content, nuclear volume and minimum mitotic cycle time. Proc. Nat. Acad. Sci., 49, 897-902. 
Wallace, D. H., Ozbun, J. L., AND munger, H. M. 1972. Physiological genetics of crop yield. Adv, in Agronomy, 24, 97-146.

Watson, D. J. 1952. The physiological basis of variation in yield. Adv. in Agronomy, 4, 101-145.

WEISS, R. R., KUKORA, J. R., AND ADAMS, J. 1975. The relationship between enzyme activity, cell geometry, and fitness in Saccharomyces cerevisiae. Proc. Nat. Acad. Sci. USA, 72, 794798.

yCAS, M., sugita, M., ANd BENSAm, A. 1965. A model of cell size regulation. F. Theoret. Biol., 9, 444-470. 